\title{
UPAYA MENINGKATKAN PRESTASI BELAJAR MATERI BANGUN SEGIEMPAT MELALUI MODEL DISCOVERY LEARNING PADA SISWA KELAS VII C SMP NEGERI 3 TERAS KABUPATEN BOYOLALI SEMESTER GENAP TAHUN PELAJARAN 2017/2018
}

\author{
Muh. Fakhrudin Suryana \\ Guru SMP Negeri 3 Teras Boyolali \\ fakhrudin_s3mpd@yahoo.co.id
}

\begin{abstract}
This research is motivated by the factual condition of the demand for improving the quality of education supported by the implementation of the thirteen curriculum through the discovery learning model of building a quadrilateral. This study aims to describe the improvement of learning achievement of semicircle building material through the discovery learning model in the students of class 2017/2018. Subjects and sources of research data are as many as 25 students. Data collection techniques use observation, documentation, and tests. Data analysis uses critical and comparative analysis. The indicator of success using minimum learning mastery (KBM) of 65 and 100\% completeness target class. The research procedure uses cycles. The progress of student achievement in the mathematics learning material of rectangle building, at the initial average condition is 60 and the average cycle I is 67 and the average cycle II is 80. From this data, it is clear that there is an increase in the average value of the initial condition to cycle I is 7 digits (12\%), from cycle I to cycle II there is an increase of 13 digits (19\%), from the initial condition to cycle II there is an increase of 20 digits (33\%). The highest score of learning achievement in the initial condition is 72, the first cycle is 78, and the second cycle is 92. The highest value increase from the initial condition to cycle I is 6 digits (10\%), from cycle I to cycle II there is an increase of 14 digits (18\%), and from cycle to cycle II there was a 22 digit increase (28\%). The lowest score of the initial condition is 50, the first cycle is 58, and the second cycle is 70. The lowest increase from the initial condition to cycle I is 8 digits (16\%), from cycle I to cycle II there is a 12 digit increase (21\%), and from cycle to cycle II an increase of 20 digits (40\%). Percentage of learning achievement was obtained at initial condition equal to $24 \%$ and in cycle I was $56 \%$ and cycle II was 100\%. Student achievement from the initial condition to the first cycle occurs $22 \%$ increase in class attainment, from cycle I to cycle II an increase of 44\%, and from the initial condition to cycle II an increase of $66 \%$. This means that the students' learning achievement in the mathematics learning from the initial condition until the second cycle there is a significant increase. Thus, it is affirmed that through the discovery learning model can optimize the achievement of learning material rectangle building.
\end{abstract}

Keywords: learning achievement, two-dimensional figure, discovery learning

Abstrak. Penelitian ini dilatarbelakangi oleh kondisi faktual tuntutan peningkatan mutu pendidikan yang didukung dengan pelaksanaan kurikulum tigabelas melalui model discovery learning materi bangun segiempat. Penelitian ini bertujuan 
untuk mendeskripsikan tentang peningkatan prestasi belajar materi bangun segiempat melalui model discovery learning pada siswa kelas 2017/2018. Subjek dan sumber data penelitian adalah sebanyak 25 siswa. Teknik pengumpulan data menggunakan observasi, dokumentasi, dan tes, sedangkan alat pengumpulan data menggunakan butir soal. Analisis data menggunakan analisis kritis dan komparatif. Indikator keberhasilan menggunakan ketuntasan belajar minimal (KBM) sebesar 65 dan target ketuntasan kelas $100 \%$. Prosedur penelitian menggunakan siklus.

Kemajuan prestasi belajar siswa dalam pembelajaran matematika materi bangun segiempat, pada kondisi awal rata-rata sebesar 60 dan siklus I rata-rata sebesar 67 serta siklus II rata-rata sebesar 80 . Dari data ini, tampak jelas bahwa terjadi kenaikan rata-rata nilai dari kondisi awal ke siklus I sebesar 7 digit (12\%), dari siklus I ke siklus II terjadi kenaikan sebesar 13 digit (19\%), dari kondisi awal ke siklus II terjadi kenaikan sebesar 20 digit (33\%). Nilai tertinggi prestasi belajar pada kondisi awal sebesar 72, siklus I sebesar 78, dan siklus II sebesar 92. Terjadi kenaikan nilai tertinggi dari kondisi awal ke siklus I sebesar 6 digit (10\%), dari siklus I ke siklus II terjadi kenaikan sebesar 14 digit (18\%), dan dari pasiklus ke siklus II terjadi kenaikan sebesar 22 digit (28\%). Nilai terendah dari kondisi awal sebesar 50, siklus I sebesar 58, dan siklus II sebesar 70. Terjadi kenaikan nilai terendah dari kondisi awal ke siklus I sebesar 8 digit (16\%), dari siklus I ke siklus II terjadi kenaikan sebesar 12 digit (21\%), dan dari pasiklus ke siklus II terjadi kenaikan sebesar 20 digit (40\%). Persentase ketercapaian belajar diperoleh pada kondisi awal sebesar 24\% dan pada siklus I sebesar 56\% serta siklus II sebesar 100\%. Prestasi belajar siswa dari kondisi awal ke siklus I terjadi kenaikan ketercapaian kelas sebesar $22 \%$, dari siklus I ke siklus II terjadi kenaikan sebesar $44 \%$, dan dari kondisi awal ke siklus II terjadi kenaikan sebesar $66 \%$. Hal ini bermakna bahwa prestasi belajar siswa dalam pembelajaran matematika dari kondisi awal hingga siklus II terjadi kenaikan yang signifikan. Dengan demikian, ditegaskan bahwa melalui model discovery learning mampu mengoptimalkan prestasi belajar materi bangun segiempat.

Kata kunci: prestasi belajar, bangun datar, discovery learning

\section{Pendahuluan}

Pentingnya pendidikan bagi kehidupan manusia adalah untuk mencapai harkat dan martabat manusia yang sesungguhnya, karena di dalamnya memuat motivasi berprestasi (mencapai keinginan yang terbaik), membentuk karakter yang kuat (nilai, kebenaran, sikap, perilaku yang melekat diri), dan prestasi terbaik (produk/hasil, keterampilan, kecakapan, dan sejenisnya), yang dapat diimplementasikan dalam kehidupan nyata sehari-hari dan memberikan manfaat yang luas (manusia dan alam). Penumbuhan budi pekerti atau yang sejenis disebut dengan istilah pendidikan berkarakter tertuang dalam Undang-Undang Nomor : 20 Tahun 2003 Bab II Pasal 3 yaitu : "Pendidikan nasional berfungsi mengembangkan kemampuan dan membentuk watak serta peradaban bangsa yang bermartabat, bertujuan untuk berkembangnya potensi siswa agar menjadi manusia yang beriman dan bertaqwa kepada Alloh Yang Maha Esa, berakhlak mulia, sehat, berilmu, sehat, kreatif, mandiri, dan menjadi warga negara yang demokratis serta bertanggung jawab".

Pendidikan yang didukung dengan pembelajaran yang efektif dan inovatif serta menyenangkan akan membawa kemajuan penguasaan materi dan prestasi belajar siswa, artinya secara kognitif, afektif, dan psikomotor siswa akan lebih baik dan siswa mampu berprestasi, berbeda dengan pembelajaran yang konvensional, di mana 
peran guru lebih dominan, guru sebagai pusat pembelajaran (teacher center) dan siswa hanya dijadikan sebagai objek pembelajaran yang menjadikan proses pembelajaran membosankan, tidak menarik, dan siswa tidak mendapatkan kesempatan untuk berkembang, maka hasilnya tidak optimal.

Inovasi pembelajaran memang harus dilaksanakan oleh guru agar dapat membawa perubahan dan pencerahan bagi siswa untuk mencapai cita-cita dan masa depannya lebih baik, misalnya dengan menerapkan model discovery learning. Implementasi model discovery learning dapat dijadikan titik tolak merubah paradigma lama dalam pembelajaran yaitu pembelajaran yang berpusat pada guru (teacher center) menjadi pembelajaran yang berpusat pada siswa (student center). Maka dengan model discovery learning dalam pembelajaran matematika diharapkan mampu membawa pencerahan dan perubahan yang lebih baik utamanya bagi siswa.

Model Discovery Learning memberikan kesempatan bagi siswa untuk bekerja sama dalam kelompok untuk memecahkan masalah yang diberikan oleh guru. Sehingga model ini dapat merangsang semangat siswa dalam memecahkan masalah dan membuat suasana kelas pada siswa yang mengikuti pembelajaran dengan model Discovery Learning lebih kondusif terutama pada saat kegiatan diskusi dan siswa mulai mempunyai kesadaran untuk memberikan kesempatan pada temannya yang kurang mampu untuk bergabung dalam kegiatan diskusi, bahkan untuk mewakili kelompok menyajikan hasil diskusi. Seperti Hanafiah dan Cucu (2009:22) berpendapat bahwa model Discovery Learning membangun komitmen (commitment bulding) dikalangan siswa untuk belajar, yang diwujudkan dengan keterlibatan, kesungguhan, dan loyalitas terhadap mencari dan menemukan sesuatu dalam proses pembelajaran.

Rasana menyatakan (2009:26), menyatakan pembelajran konvensional merupakan model pembelajaran yang proses pembelajarannya dimulai dari penyajian pengalaman - pengalaman yang berkaitan dengan konsep yang akan dipelajari, dilanjutkan dengan pemberian informasi oleh guru, Tanya jawab, pemberian tugas oleh guru, pelaksanaan tugas oleh siswa sampai pada akhirnya guru merasa bahwa apa yang telah diajarkan dimengerti oleh siswa. Sehingga, siswa hanya menyalin dan mencatat apa yang diberikan oleh guru dan hanya menerapkan konsep yang diberikan oleh guru dan siswa tidak diberikan kesempatan untuk menggali pengetahuannya sendiri.

Implementasi model discovery learning ini dipandang perlu dan penting, karena selama ini dalam pelaksanaan pembelajaran Matematika materi bangun Segiempat masih rendah, artinya rata-rata masih di bawah ketuntasan belajar minimal (KBM) yang ditetapkan di SMP Negeri 3 Teras Kabupaten Boyolali semester genap tahun pelajaran 2017/2018 yang sudah menerapka Kurikulum Tigabelas untuk kelas VII (tujuh), yaitu sebesar 65. dari enam (6) kelas VII A, B, C, D, E, dan F dapat disajikan hasil penilaian harian berikut ini.

Tabel 1. Nilai Rata-rata Penilaian Harian Materi Segiempat pada Siswa Kelas VII SMP Negeri 3 Teras Kabupaten Boyolali Semester Genap Tahun Pelajaran 2017/2018

\begin{tabular}{ccccc}
\hline No. & Kelas & Nilai Rata-rata & KBM & Keterangan \\
\hline 1. & VII A & 61,23 & 65 & Tidak tercapai \\
2. & VII B & 62,42 & 65 & Tidak tercapai \\
3. & VII C & 56,14 & 65 & Tidak tercapai \\
4. & VII D & 61,55 & 65 & Tidak tercapai \\
5. & VII E & 63,71 & 65 & Tidak tercapai \\
6. & VII F & 62,87 & 65 & Tidak tercapai \\
\hline
\end{tabular}

Sumber: Data diolah 2018. 
Selanjutnya dapat disajikan diagram nilai rata-rata penilaian harian materi segiempat pada siswa kelas VII SMP Negeri 3 Teras
Kabupaten Boyolali semester genap tahun pelajaran 2017/2018 berikut ini.

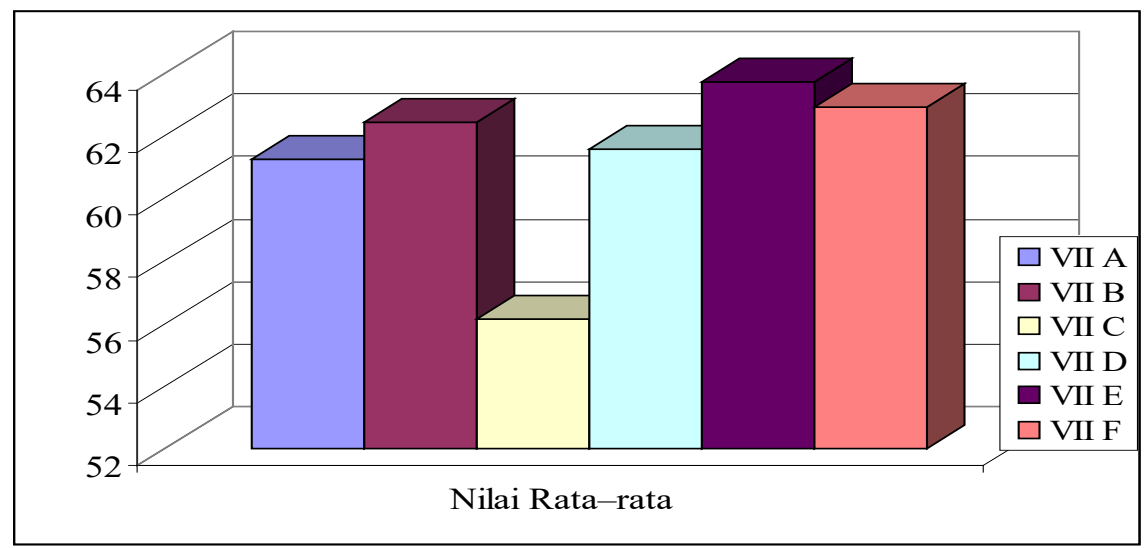

Gambar 1. Nilai Rata-rata Penilaian Harian Materi Segiempat pada Siswa Kelas VII SMP Negeri 3 Teras Kabupaten Boyolali Semester Genap Tahun Pelajaran 2017/2018

Dipilih dan ditetapkannya kelas VII $\mathrm{C}$ sebagai subjek penelitian dengan alasan bahwa nilai rata-rata penilaian harian yang paling rendah untuk materi bangun Segiempat. Untuk itu, peneliti mencoba untuk mencari solusi yang tepat dan efektif serta inovatif dengan cara memilih dan menerapkan model discovery learning. Hal ini mengingat bahwa Kurikulum 2013 yaitu "kurikulum yang menyempurnakan pola pembelajaran yang berpusat pada guru menjadi pola pembelajaran yang berpusat pada siswa, pola pembelajaran satu arah menjadi interaktif dan pola pembelajaran pasif menjadi pembelajaran aktif mencari" (dalam Permendikbud No. 65 Tahun 2013). Dalam hal ini guru hanya sebagai pembimbing dan fasilitator siswa agar mampu mengembangkan potensinya secara optimal. Salah satu model pembelajaran yang mampu mengembangkan peran guru sebagai pembimbing dan fasilitator untuk mengembangkan potensi siswa yaitu model pembelajaran disscovery learning.

Dari uraian tersebut, peneliti tertarik untuk meneliti tentang : "Upaya Meningkatkan Prestasi Belajar Materi Bangun Segiempat melalui Model Discovery Learning pada Siswa Kelas VII C SMP Negeri 3 Teras Kabupaten Boyolali Semester Genap Tahun Pelajaran 2017/2018".
Berdasarkan latar belakang, pembatasan, dan identifikasi masalah tersebut di atas, dapat dirumuskan masalah berikut ini: Apakah melalui model discovery learning dapat meniningkatkan prestasi belajar materi segiempat pada siswa kelas VII C SMP Negeri 3 Teras Kabupaten Boyolali semester genap tahun pelajaran 2017/2018? Selanjutnya, tujuan yang hendak dicapai, yaitu tujuan umum, ingin mengetahui tentang kondisi nyata kegiatan pembelajaran di SMP Negeri 3 Teras Boyolali, sedangkan tujuan khusus, yaitu ingin mengetahui apakah ada peningkatan prestasi belajar materi bangun Segiempat melalui penerapan model discovery learning pada siswa kelas VII C SMP Negeri 3 Teras Kabupaten Boyolali semester genap tahun pelajaran 2017/2018.

Manfaat yang diharapkan dari penelitian, yaitu manfaat teoritis, antara lain: mendapatkan deskripsi teoritis tentang model pembelajaran discovery learning, dapat menambah referensi di perpustakaan sekolah, dan dengan penelitian tindakan kelas ini dapat dikembangkan penelitian sejenis berikutnya oleh peneliti yang lain. Sedangkan manfaat praktis, antara lain: bagi siswa, dapat meningkatkan prestasi belajar matematika khususnya bangun Segiempat; bagi guru Matematika SMP dapat dipergunakan 
sebagai rujukan tentang implementasi model discovery learning dalam upaya meningkatkan mutu pembelajaran sesuai dengan indikator yang berdampak positif pada siswa; dan bagi sekolah SMP Negeri 3 Teras Boyolali dalam upaya meningkatkan mutu kinerja guru baik dalam pembelajaran maupun pengembangan profesi serta prestasi belajar siswa.

Beragam pendapat muncul mengenai pengertian Matematika diantaranya yang dikemukakan oleh Reys (dalam Suherman, dkk., 2013:17) mengatakan matematika adalah telaah tentang pola dan hubungan, suatu jalan atau pola berpikir, suatu seni, suatu bahasa, dan suatu alat. Matematika merupakan ilmu universal yang mendasari perkembangan teknologi modern, yang mempunyai peran penting dalam berbagai disiplin dan memajukan daya pikir manusia. Matematika merupakan ilmu universal yang mendasari perkembangan teknologi modern, yang mempunyai peran penting dalam berbagai disiplin dan memajukan daya pikir manusia. Istilah Matematika berasal dari perkataan latin mathematica, yang mulanya berasal dari perkataan Yunani mathematike, yang secara etimologis menurut Elea Tinggih (dalam Suherman, dkk., 2013:16) mengatakan bahwa "perkataan Matematika berarti ilmu pengetahuan yang diperoleh dengan bernalar" dalam hal ini Matematika lebih menekankan pada penalaran, bukan dari hasil observasi ataupun hasil eksperimen.

Matematika SMP merupakan pelajaran matematika yang diajarkan di Sekolah Menengah Pertama. Matematika SMP terdiri atas bagian-bagian matematika yang dipilih dan ditetapkan untuk menumbuhkembangkan potensi siswa atau siswa sesuai dengan taraf perkembangan mental spiritual, kognitif, afektif, dan psikomotornya yang diharapkan mampu menghasilkan kemampuan-kemampuan dan membentuk pribadi serta sinergi dengan perkembangan ilmu pengetahuan dan teknologi yang dapat membawa manfaat bagi dirinya sendiri dan lingkungannya (masyarakat, bangsa, dan negara serta alam). Hal ini menunjukkan matematika sekolah (SMP) tetap memiliki karakteristik, seperti objek atau kejadian yang bersifat abstrak hingga konkrit serta menggunakan kerangka pikir deduktif.

Pembelajaran yang menekankan pada pembelajaran siswa aktif dalam menemukan konsep sendiri diantaranya adalah metode discovery (Kemendikbud, 2013). Pembelajaran discovery (discovery learning) merupakan suatu model pembelajaran yang dikembangkan oleh J. Bruner berdasarkan pada pandangan kognitiftentang pembelajaran dan prinsip-prinsip konstruktivis (Depdiknas, 2005).

Di dalam discovery learning siswa didorong untuk belajar sendiri secara mandiri, sebagaimana diungkapkan oleh Ilahi (2012: 30). Pada dasarnya discovery learning tidak jauh berbeda dengan pembelajaran inquiry, namun pada disco-very learning masalah yang diperhadapkan kepada siswa semacam masalah yang direkayasa oleh guru, sehingga siswa tidak harus mengerahkan seluruh pikiran dan keterampilannya untuk mendapatkan temuan-temuan di dalam masalah itu melalui proses penelitian (Kemendikbud, 2013).

Model pembelajaran yang baik adalah model pembelajaran yang mampu untuk membimbing siswa di dalam pembelajaran secara aktif sehingga tercapai tujuan dari pembelajaran secara optimal. Oleh karena itu, dibutuhkan inovasi didalam pembelajaran matematika (Oktara, Setyaningsih, dan Kholid. 2015:63). Menurut Hamalik dalam Ilahi (2012: 29) menyatakan bahwa discovery adalah proses pembelajaran yang menitik beratkan pada mental intelektual para anak didik dalam memecahkan berbagai persoalan yang dihadapi, sehingga menemukan suatu konsep atau generalisasi yang dapat diterapkan dilapangan.

Model pembelajaran discovery merupakan suatu metode pengajaran yang menitikberatkan pada aktivitas siswa dalam belajar. Dalam proses pembelajaran dengan metode ini, guru hanya bertindak sebagai pembimbing dan fasilitator yang 
mengarahkan siswa untuk menemukan konsep, dalil, prosedur, algoritma dan semacamnya (Purileila, 2016:88). Discovery learning adalah suatu tipe pembelajaran dimana siswa membangun pengetahuan mereka sendiri dengan mengadakan suatu percobaan dan menemukan sebuah prinsip dari hasil percobaan tersebut". "Discovery learning merupakan komponen dari praktek pendidikan yang meliputi metode mengajar yang memajukan cara belajar aktif, berorientasi pada proses, mengarahkan sendiri dan reflektif (Suryosubroto, 2012:192).

Dengan demikian, Discovery learning berupaya untuk membangun semangat belajar siswa, meningkatkan peran aktif siswa, menugasi siswa untuk bertanggung jawab dalam menghadapi dan menyelesaikan berbagai permasalahan belajarnya secara mandiri dan kolaboratif dengan teman sejawat dan sewaktu-waktu melibatkan bimbingan gurunya.

Berdasarkan latar belakang masalah dan perumusan masalah dapat diajukan hipotesis tindakan, yaitu: melalui penerapan model discovery learning dapat meningkatkan prestasi belajar materi bangun segiempat pada siswa kelas VII C SMP Negeri 3 Teras Kabupaten Boyolali semester genap tahun pelajaran 2017/2018.

\section{Metode}

Penelitian tindakan kelas ini berlangsung selama dua bulan, dimulai tanggal 3 Januari sampai dengan 3 April 2018. Penelitin ini dilakukan di SMP Negeri 3 Teras Boyolali semester genap tahun pelajaran 2017/2018. Subjek penelitian adalah siswa VII C SMP Negeri 3 Teras Boyolali semester genap tahun pelajaran2017/2018 sebanyak 25 siswa. Sumber data dalam penelitian ini adalah kolaborator, siswa, dan referensi dan atau sumber data tertulis lsejenis. Teknik pengumpulan data menggunakan angket motivasi, observasi selama dan setelah dilaksanakan pembelajaran, dokumentasi, dan tes tertulis. Validitas data, jika terbukti nyata ada peningkatan afektif, kognitif, dan psikomotor dalam pembelajaran, maka data yang digunakan adalah valid. Penelitian ini adalah penelitian tindakan kelas, jadi tidak perlu menggunakan analisis statistik untuk menguji validitas data.

Teknik analisis data dalam penelitian ini menggunakan analisis kritis dan analisis komparatif. Teknik analisis kritis melaksanakan kegiatan mengungkap kelemahan dan kelebihan tindakan dan hasil dalam proses pembelajaran berdasarkan kriteria. Hasil analisis kritis dijadikan dasar dalam penyusunan perencanaan tindakan tahap berikutnya. Analisis kritis mencakup hasil angket, observasi, dan tes. sedangkan analisis komparatif adalah membandingkan data antarsiklus, kondisi awal dengan siklus pertama, dan seterusnya. Hasil analisis komparatif untuk mengetahui keberhasilan maupun kegagalan dalam setiap siklusnya.

Tindakan dalam penelitian menggunakan model Kemmis dan Mc Taggart. Model ini menggunakan siklus sistem spiral, masingmasing siklus terdiri dari empat komponen, yaitu rencana, tindakan, observasi dan refleksi. Rencana (planning), tindakan apa yang akan dilakukan penelitian untuk memperbaiki, meningkatkan proses dan hasil belajar di kelas. Tindakan (acting), apa yang dilakukan oleh peneliti sebagai upaya memperbaiki dan meningkatkan kondisi pembelajaran yang ada sehingga kondisi yang diharapkan dapat tercapai. Pegamatan (Observing), peneliti mengamati hasil atau dampak dari tindakannya. Refleksi (reflecting), peneliti mengkaji melihat dan mempertimbangkan atas dampak dari tindakan dengan menggunakan berbagai kriteria. Dari hasil refleksi tersebut peneliti melakukan memodifikasi terhadap rencana tindakan berikutnya (Suwandi, 2009).

Penelitian ini menetapkan indikator kinerja dari kondisi awal (kondisi awal) ke siklus berikutnya, bila sudah optimal atau ada peningkatan partisipasi aktif dan perubahan sikap, kterampilan, dan intelektual, maka tindakan dihentikan. Intinya ada peningkatan hasil belajar siswa lebih baik sesuai ketuntasan 
belajar minimal (KBM) sebesar 65 dan ketuntasan kelas $100 \%$. Prosedur penelitian ini menggunakan siklus.

\section{Hasil}

\section{Kondisi awal}

Pembelajaran berlangsung secara konvensional, belum sesuai tujuan, mengingat siswa belum menunjukkan keterlibatannya secara aktif, kondusif, dan motivasinya belum optimal, karakter siswa yang belum terbina dengan baik, peran guru belum optimal, lingkungan sekolah yang belum kondusif, dan sebagainya. Suasana pembelajaran pada kondisi awal atau sebelum ada tindakan mulai dari kesiapan guru dalam pembelajaran, kegiatan guru dalam mempersiapkan kelas untuk pembelajaran, persiapan kelas untuk pembelajaran, motivasi, dan prestasi belajar siswa belum optimal, artinya belum sesuai dengan batas minimal yang telah ditetapkan untuk seluruh siswa. Hasil observasi guru dalampembelajaranmulaidarimenyampaikan tujuan pembelajaran, menyampaikan apersepsi, memberi motivasi, membimbing siswa, memberi kesempatan siswa untuk bertanya, memberi tugas, mengumpulkan tugas, memeriksa tugas, dan antusiasisme siswa mencapai klasifikasi penilaian rendah atau sebesar $48 \%$, dan belum optimal, karena peneliti menetapkan batas minimal $65 \%$. Hasil observasi guru dalam mempersiapkan kelas untuk pembelajaran mulai dari kelas yang bersih dan sehat, kelengkapan meja kursi guru dan siswa, presensi siswa, jadwal pembelajaran di kelas, dan piket siswa, suasana kelas untuk pembelajaran yang nyaman hingga pencap[aian tujuan pembelajaran mencapai klasifikasi penilaian rendah atau sebesar $56 \%$, dan belum optimal, karena peneliti menetapkan batas minimal $65 \%$.

Secara terperinci motivasi siswa kondisi awal (sebelum ada tindakan) dalam pembelajaran materi bangun segiempat dengan nilai rata-rata sebesar 60 , nilai tertinggi sebesar 77, nilai terendah sebesar 51, tercapai dan atau melampaui KBM sebanyak 5 siswa
(20\%), sisanya sebanyak 20 siswa $(80 \%)$ belum tercapai, karena peneliti menetapkan $100 \%$. Sedangkan prestasi belajar siswa dengan nilai rata-rata sebesar 60 , nilai tertinggi sebesar 72, nilai terendah sebesar 50, tercapai dan atau melampaui KBM sebanyak 6 siswa (24\%), isanya 19 siswa (76\%) belum tercapai dan atau belum melampaui KBM. Dengan memperhatikan hasil pembelajaran pada kondisi awal atau prasiklus ini tersebut, peneliti perlu melaksanakan tindakan lebih lanjut, yaitu siklus I dengan menerapkan discovery learning. Mencermati hasil kegiatan pembelajaran kondisi awal tersebut, perlu peneliti melaksanakan tindakan berikutnya, yaitu siklus I dengan menerapkan model discovery learning.

\section{Siklus I}

Pembelajaran dibagi menjadi kelompokkelompok kecil, setiap kelompok anggotanya antara 3 sampai dengan 4 siswa. Kondisi pembelajaran sudah mulai tampak antusias, motivasi belajar siswa mulai meningkat lebih baik, komunikasi dan interaksi antarsiswa sudah mulai efektif dan dalam bimbingan guru yang mulai terkondisi dengan baik dan menyenangkan. Siswa berani mengacungkan jari untuk menjawab pertanyaan guru. Kemudian, guru menunjuk seorang siswa putri untuk mendemonstraikan hasil kerja kelompoknya, kemudian guru mengamati hasil pekerjaan siswa tersebut, sambil mengkomunikasikan hasilnya pada peserta diskusi, apakah hasil pekerjaan tersebut sudah benar. Semua siswa mengamati, mencocokkan pekerjaannnya, ternyata sudah benar, meskipun ada beberapa yang belum benar. Hasil observasi guru dalam pembelajaran mulai dari menyampaikan tujuan pembelajaran dengan jelas hingga pencapaian yujuan pembelajaran mencapai klasifikasi penilaian cukup dan belum optimal sebesar $76 \%$, peneliti menetapkan 65 , masih perlu ditingkatkan atau dioptimalkan, antara lain menyampaikan materi pelajaran dengan jelas, Membimbing siswa secara rutin dan terstruktur, dan memberi kesempatan siswa 
bertanya, maka perlu ditindaklanjuti pada siklus II.

Hasil observasi guru dalam kesiapan kelas untuk pembelajaran mulai dari kelas yang bersih dan sehat, kelengkapan dan kerapihan meja kursi guru dan siswa hingga suasana kelas yang nyaman, aman, dan menyenangkan untuk pembelajaran mulai optimal, secara keseluruhan sudah mengalami perubahan dan kemajuan yang semula di kondisi awal sebesar $48 \%$, sedangkan pada siklus I sebesar $64 \%$, ada kenaikan sebesar 16\%. Pada kondisi awal 64\% masih di bawah KBM sebesar 65\%., namun masih perlu ditindaklanjuti atau dioptimalkan pada siklus II mulai kelas yang bersih, meja dan kursi siswa dan guru. Motivasi siswa dalam pembelajaran matematika, diperoleh nilai rata-rata 76 sudah terlampau namun masih ada 6 siswa (22\%) yang belum tercapai. namun belum mencapai $100 \%$, maka perlu ditindaklanjuti siklus II. Penumbuhan budi pekerti (pendidikan karakter) siswa dalam pembelajaran matematika, diperoleh nilai rata-rata 78 dalam klasifikasi terlampaui, namun masih ada 6 siswa (22\%) yang belum tercapai. Tercapai atau terlampaui, belum mencapai $100 \%$, maka perlu ditindak-lanjuti siklus II.

Guru melaksanakan kegiatan memotivasi dan membimbing siswa sebagaimana yang terjadi pada tahap kondisi awal, tetapi ada penekanan pada kegiatan siswa melakukan baris secara tertib dan disiplin sebelum memasuki kelas, dilanjutkan untuk berjabatan tangan dengan guru. Hal ini bertujuan untuk menciptakan suasana familiar, keakraban antara guru dan siswa, bermanfaat untuk media saling memaafkan antara guru dan siswa, dan setelah memasuki kelas, dilaksanakan berdo'a bersama dipandu, dan dipimpin ketua kelasnya. Setelah berdo'a, guru memberikan ucapan salam dan selamat kepada siswa, bahwa masih diberi kesempatan Alloh subhanahu wata'ala untuk bertemu dan belajar bersama kembali dalam suasana sehat, bahagia, dan menikmati kebersamaan. Kemudian, guru memberikan pengantar arti pentingnya berdo'a bagi kita semua, di samping sebagai makhluk ciptaan Alloh, manusia wajib mencari ilmu bagi masa depan kita. Guru juga menyampaikan arti pentingnya bekerjasama dengan teman atau orang lain, manusia juga merupakan makhluk sosial, membutuhkan orang lain dan saling menghargai, manusia hidup kalau bersama orang lain. Dalam siklus I ini, siswa mengalami perubahan perilaku yang lebih baik, siswa mulai peduli pada dirinya sendiri, peduli kepada orang lain, sekaligus peduli kepada Alloh, sehingga dapat dicapai bahwa manusia sebagai makhluk pribadi, makhluk sosial, sekaligus makhluk ciptaan Alloh.

\section{Siklus II}

Pembelajaran menurut Diaz Carlos (dalam Sumantri, 2015:2) merupakan akumulasi dari konsep mengajar (teaching) dan konsep belajar (learning). Menurut Gegne, dkk (dalam Rusmono, 2012:6), pembelajaran adalah serangkaian kegiatan yang dirancang untuk memungkinkan terjadinya proses belajar pada siswa. Miarso (dalam Rusmono, 2012:6), mengemukakan bahwa pembelajaran adalah suatu usaha yang disengaja, bertujuan, dan terkendali agar orang lain belajar atau terjadi perubahan yang relatif menetap pada diri orang lain. Smith dan Ragan (dalam Rusmono, 2012:6) mengemukakan bahwa pembelajaran merupakan aktivitas penyampaian informasi dalam membantu siswa mencapai tujuan, khususnya tujuan-tujuan belajar, tujuan siswa dalam belajar.

Dari uraian di atas, dapat dipahami bahwa pembelajaran merupakan suatu upaya untuk menciptakan suatu kondisi bagi tercapainya suatu kegiatan belajar yang memungkinkan siswa memperoleh pengalaman belajar yang memadai. Menindaklanjuti siklus I, pada tahap siklus II ini, peneliti selanjutnya melaksanakan pembelajaran dibagi menjadi kelompok-kelompok kecil, setiap kelompok anggotanya antara 3 sampai dengan 4 siswa. Kondisi pembelajaran tampak sinergis, optimal, dan antusias, semangat dan kerjasama 
dalam belajar siswa meningkat lebih baik, suasana pembelajaran kreatif, siswa berani menyampaikan pendapat, baik berupa menjawab pertanyaan, mengoreksi jawaban teman hingga menyampaikan suatu bentuk penyusunan kesimpulan, di antara siswa saling komunikasi dan interaksi positif, sudah efektif dan dalam bimbingan guru yang mulai terkondisi dengan baik dan menyenangkan. Siswa berani mengacungkan jari untuk menjawab pertanyaan guru. Kemudian, guru menunjuk seorang siswa putri untuk mendemonstraikan hasil kerja kelompoknya, kemudian guru mengamati hasil pekerjaan siswa tersebut, sambil mengkomunikasikan hasilnya pada peserta diskusi, apakah hasil pekerjaan tersebut sudah benar.

Dalam siklus II ini, siswa belajar merupakan proses yang harus ditempuh seseorang dalam mencapai kemajuan dalam hidupnya, baik secara formal maupun nonformal. Seseorang dikatakan telah mengalami pembelajaran jika dalam dirinya terjadi perubahan berupa kemampuan, ketrampilan, nilai, dan perilaku yang bermanfaatbagi diri sendirimaupun oranglain. Perubahan-perubahan tersebut terjadi dengan tahapan-tahapan tertentu dan berlangsung dalam waktu yang relatif lama dan perubahan itu terjadi karena adanya usaha. Semua siswa mengamati, mencocokkan pekerjaannnya, ternyata sudah benar, meskipun ada beberapa yang belum benar. Hasil observasi guru dalam pembelajaran mulai dari menyampaikan tujuan pembelajaran dengan jelas hingga pencapaian yujuan pembelajaran mencapai klasifikasi penilaian cukup dan belum optimal sebesar $76 \%$, peneliti menetapkan 65 , masih perlu ditingkatkan atau dioptimalkan, antara lain menyampaikan materi pelajaran dengan jelas, Membimbing siswa secara rutin dan terstruktur, dan memberi kesempatan siswa bertanya.

Hasil observasi guru dalam kesiapan kelas untuk pembelajaran mulai dari kelas yang bersih dan sehat, kelengkapan dan kerapihan meja kursi guru dan siswa hingga suasana kelas yang nyaman, aman, dan menyenangkan untuk pembelajaran mulai optimal, secara keseluruhan sudah mengalami perubahan dan kemajuan yang semula pada siklus I sebesar $64 \%$, sedangkan pada siklus II sebesar $76 \%$, ada kenaikan sebesar 12\%. Tindakan hasil observasi guru dalam persiapan pembelajaran pada pada siklus I sebesar $80 \%$, dan siklus II sebesar 94\%, ada kenaikan 14\%, sudah melampaui KBM sebesar 65\%. Motivasi siswa dalam pembelajaran matematika, diperoleh nilai rata-rata 74 , nilai tertinggi sebesar 87 , nilai terrendah sebesar 68, dan secara keseluruhan atau sebanyak 25 siswa $(100 \%)$ sudah mencapai atau melampaui KBM. Sedangkan untuk prestasi belajar, nilai rata-rata sebesar 80, nilai tertinggi sebesar 92, nilai terendah sebesar 70, ketuntasan kelas mencapai $100 \%$ atau sebanyak 25 siswa sudah melampaui KBM. Dengan demikian, dapat ditegaskan bahwa sudah optimal, penelitian tindakan kelas dihentikan.

\section{Pembahasan}

Pembahasan Tiap Siklus

Tahap kondisi awal, siswa masih belum optimal, masih banyak kelemahan dan kekurangan, seperti semangat belajar siswa yang belum terbangun dengan baik berupa siswa masih kurang peduli pada kerjasama dalam piket kelas, masih ada sebagian siswa yang tidak memperhatikan penjelasan guru, dan tanggung jawab siswa ketika diberi pekerjaan rumah tidak diselesaikan, kebersihan kelas belum optimal, dan sebagainya.

Pada tahap siklus I atau setelah ada tindakan pertama mengalamiperubahan atau peningkatan yang lebih baik, siswa hadir tepat waktu, sebelum memasuki ruangan berbaris tertib dalam antrian bersama, memasuki kelas dan mengakhir pembelajaran berjabatan tangan dengan guru, perhatian siswa lebih fokus, pembelajaran tenang dan lebih nyaman, siswa mulai berani bertanya, kondisi diskusi lebih hidup dan kompetitif, meskipun masih ada siswa yang belum optimal. 
Tahap siklus II atau tindakan kedua, sudah berlangsung secara optimal, baik implementasi penumbuhan budi pekerti (pendidikan karakter)nya maupun prestasi belajar siswa sudah mencapai optimal, karakter siswa mulai tampak meningkat lebih baik, siswa mulai peduli dalam segala kegiatan pembelajaran, tugas guru dilaksanakan dengan baik, diskusi berjalan lancar dan tumbuh kompetisi untuk menguasai materi serta unjuk kerja di depan kelas, motivasi optimal atau mengalami peningkatan yang meyakinkan, dan prestasi belajar siswa mencapai $100 \%$ tercapai, dengan nilai melampaui batas minimal.

\section{Pembahasan Antarsiklus}

Hasil temuan guru, mulai dari kondisi awal atau kondisi awal hingga siklus II terjadi kesinambungan yang tidak terputus, terbukti bahwa guru mampu melaksanakan kolaborasi dengan teman sejawat dalam mengimplementasikan model discovery learning dalam pembelajaran materi bangun segiempat, ada peningkatan guru dalam kesiapan dan persiapan pembelajaran, motivasi belajar siswa yang meningkat, dan prestasi belajar siswa yang mengalami peningkatan secara meyakinkan.

\section{Kesiapan Guru dalam Pembelajaran}

Kesiapan guru dalam pembelajaran merupakan suatu upaya yang dilaksanakan oleh guru untuk melaksanakan dari awal hingga akhir pembelajaran, misalnya pendahuluan, yang meliputi kegiatan menyampaikan do'a bersama, menyampaikan salam, menyampaikan tujuan dengan jelas, apersepsi dan menarik kesimpulan awal, memotivasi siswa; kegiatan inti (dominan siswa), misalnya memberi kesempatan siswa membaca/ mengamati, memberi kesempatan siswa menanya, memberi kesempatan siswa menalar, memberi kesempatan siswa mencoba, memberi kesempatan siswa membentuk jejaring, membimbing siswa; dan merangkum materi, meliputi kegiatan memberi tugas atau soal setiap pertemuan, mengumpulkan tugas setiap pertemuan, memeriksa semua tugas siswa setiap pertemuan. Di samping itu, juga melaksanakan kegiatan tentang membangun suasana kelas yang kondusif dan menyenangkan untuk pembelajaran, misalnya meningkatkan antusias siswa, dan guru, pengelolaan waktu efektif, pembelajaran sesuai rencana, dan pencapaian tujuan pembelajaran. data kemajuan hasil observasi guru dalam kesiapan pembelajaran kondisi awal, siklus I, dan siklus II dapat disajikan berikut ini.

Tabel 2. Data Kemajuan Hasil Observasi Guru dalam Kesiapan Pembelajaran Kondisi awal, Siklus I,

Siklus II

\begin{tabular}{cccccccc}
\hline & & \multicolumn{3}{c}{ Tahapan Siklus } & \multicolumn{3}{c}{ Persentase Kenaikan } \\
\cline { 3 - 7 } No. & Perincian & $\begin{array}{c}\text { Kondisi } \\
\text { Awal }\end{array}$ & $\begin{array}{c}\text { Siklus } \\
\text { I }\end{array}$ & $\begin{array}{c}\text { Siklus } \\
\text { II }\end{array}$ & $\begin{array}{c}\text { Kondisi } \\
\text { Awal ke } \\
\text { Siklus I }\end{array}$ & $\begin{array}{c}\text { Siklus } \\
\text { I ke } \\
\text { Siklus II }\end{array}$ & $\begin{array}{c}\text { Kondisi } \\
\text { Awal ke } \\
\text { Siklus II }\end{array}$ \\
\hline $\begin{array}{l}\text { \% ketercapaian } \\
\text { hasil observasi } \\
\text { guru dalam pem- } \\
\text { belajaran }\end{array}$ & $48 \%$ & $64 \%$ & $76 \%$ & $16 \%$ & $12 \%$ & $28 \%$ \\
1. & & & & & & & \\
\hline
\end{tabular}

Sumber: Data diolah 2018

Disajikan diagram data kemajuan hasil observasi guru dalam kesiapan pembelajaran kondisi awal, siklus I, siklus II berikut ini. 


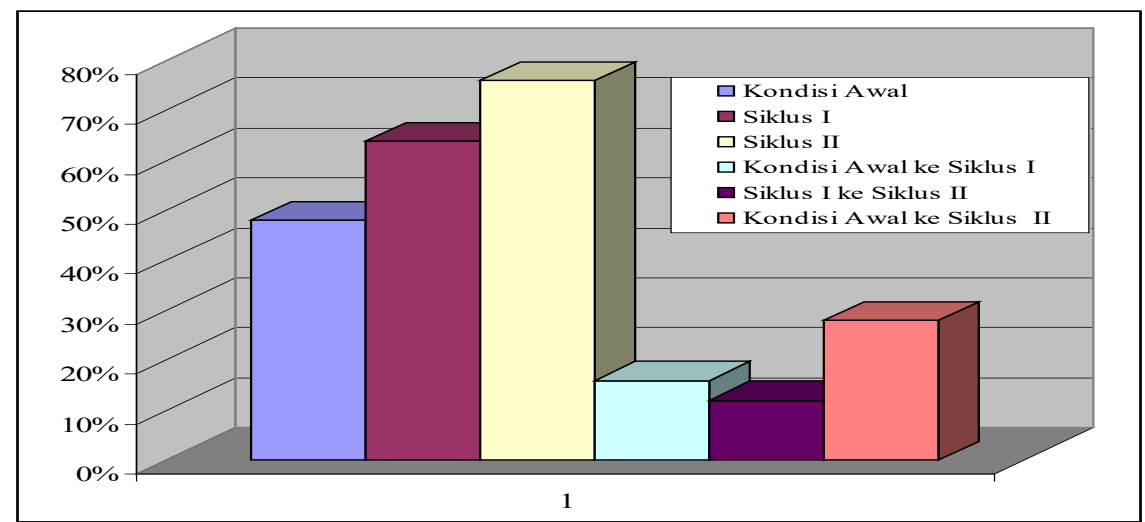

Gambar 2. Hasil Observasi Guru dalam Kesiapan Pembelajaran Kondisi awal, Siklus I, Siklus II

Hasil tindakan dari dari kondisi awal hingga siklus II, diperoleh data kemajuan guru dalam kesiapan pembelajaran, pada kondisi awal sebesar $48 \%$, siklus I sebesar $64 \%$ dan siklus II sebesar $76 \%$. Dari data ini menunjukkan bahwa ada kemajuan kesiapan guru dalam pembelajaran dari kondisi awal ke siklus I sebesar 16\%, kemudian dari siklus I ke siklus II terjadi kenaikan sebesar $12 \%$ serta dari kondisi awal ke siklus II sebesar $28 \%$. Dengan demikian, hasil obervasi guru dalam pembelajaran menunjukkan peningkatan yang signifikan.

\section{Persiapan Kelas untuk Pembelajaran}

Persiapan guru dalam pembelajaran merupakan suatu upaya yang dilaksanakan oleh guru untuk melaksanakan kegiatan mulai dari kelas bersih, kelas sehat, meja siswa lengkap dan bersih, kursi siswa lengkap dan bersih, meja guru bersih, kursi guru bersih, tersedia presensi siswa, tersedia jadwal pembelajaran, tersedia jurnal pembelajaran, tersedia jadwal piket siswa, tersedia alat peraga pembelajaran, tersedia media pembelajaran, tersedia penerangan yang cukup, kelas aman untuk belajar, kelas menyenangkan untuk belajar, kelas nyaman untuk belajar, siswa membawa alat tulis lengkap, guru membawa perangkat pembelajaran lengkap, siswa tepat waktu masuk kelas saat pembelajaran, dan guru tepat waktu masuk kelas saat pembelajaran. Data kemajuan hasil observasi guru dalam persiapan kelas untuk pembelajaran kondisi awal, siklus I, dan siklus II dapat disajikan berikut ini.

Tabel 3. Data Kemajuan Hasil Observasi Guru dalam Persiapan Kelas untuk Pembelajaran Kondisi awal, Siklus I, Siklus II

\begin{tabular}{|c|c|c|c|c|c|c|c|}
\hline \multirow{2}{*}{ No. } & Perincian & \multicolumn{2}{|c|}{ Tahapan Siklus } & \multicolumn{2}{|c|}{ Persentase Kenaikan } \\
\cline { 2 - 7 } & $\begin{array}{c}\text { Kondi- } \\
\text { si Awal }\end{array}$ & $\begin{array}{c}\text { Siklus } \\
\text { I }\end{array}$ & $\begin{array}{c}\text { Siklus } \\
\text { II }\end{array}$ & $\begin{array}{c}\text { Kondi- } \\
\text { si } \\
\text { Awal } \\
\text { ke } \\
\text { Siklus I }\end{array}$ & $\begin{array}{c}\text { Siklus } \\
\text { I }\end{array}$ & $\begin{array}{c}\text { Kondisi } \\
\text { Siklus II } \\
\text { Awal } \\
\text { ke } \\
\text { Siklus II }\end{array}$ \\
\hline 1. & $\begin{array}{l}\text { Persentase keterca- } \\
\text { paian hasil observasi } \\
\text { guru dalam per- } \\
\text { siapan kelas untuk } \\
\text { pembelajaran }\end{array}$ & $56 \%$ & $80 \%$ & $94 \%$ & $24 \%$ & $14 \%$ & $38 \%$ \\
\hline
\end{tabular}

Sumber : Data diolah 2018 
Disajikan diagram data kemajuan pembelajaran kondisi awal, siklus I, siklus hasil observasi guru dalam persiapan II berikut ini.

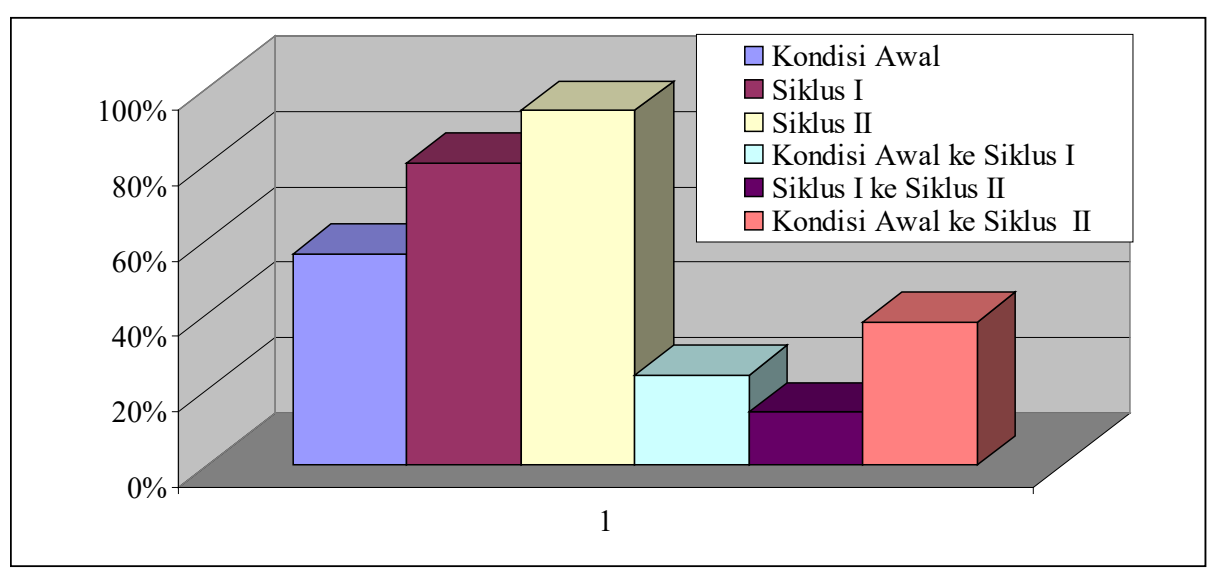

Hasil tindakan dari kondisi awal hingga siklus II, diperoleh data kemajuan guru dalam mempersiapkan kelas untuk pembelajaran, pada kondisi awal sebesar 56\%, siklus I sebesar $80 \%$ dan siklus II sebesar $94 \%$. Dari data ini menunjukkan bahwa ada kemajuan persiapan kelas untuk pembelajaran dari kondisi awal ke siklus I sebesar 24\%, kemudian dari siklus I ke siklus II terjadi kenaikan sebesar 14\% serta dari kondisi awal ke siklus II sebesar 38\%. Dengan demikian, hasil obervasi guru dalam mempersiapkan kelas untuk pembelajaran menunjukkan peningkatan yang signifikan.

\section{Motivasi siswa dalam pembelajaran}

Hasil tindakan dari kondisi awal hingga siklus II, diperoleh data kemajuan motivasi siswa dalam pembelajaran matematika, pada kondisi awal rata-rata sebesar 60 dan siklus I rata-rata sebesar 66 serta siklus II rata-rata sebesar 74. Dari data ini, tampak jelas bahwa terjadi kenaikan rata-rata nilai dari kondisi awal ke siklus I sebesar 6 digit (10\%), dari siklus I ke siklus II terjadi kenaikan sebesar 8 digit (12\%), dari kondisi awal ke siklus II terjadi kenaikan sebesar 14 digit (23\%). Nilai tertinggi motivasi pada kondisi awal sebesar 77 siklus I sebesar 80 dan siklus III sebesar 87 . Terjadi kenaikan nilai tertinggi dari kondisi awal ke siklus I sebesar 3 digit (4\%), dari siklus I ke siklus II terjadi kenaikan sebesar 7 digit (9\%), dan dari pasiklus ke siklus II terjadi kenaikan sebesar 10 digit (13\%). Data nilai terendah dari kondisi awal sebesar 51, siklus I sebesar 58, dan siklus II sebesar 68. Terjadi kenaikan nilai terendah dari kondisi awal ke siklus I sebesar 7 digit (14\%), dari siklus I ke siklus II terjadi kenaikan sebesar 10 digit (17\%), dan dari pasiklus ke siklus II terjadi kenaikan sebesar 17 digit (33\%).

Tabel 4. Data Kemajuan Motivasi Belajar Siswa Kondisi awal, Siklus I, Siklus II

\begin{tabular}{|c|c|c|c|c|c|c|c|}
\hline \multirow[b]{2}{*}{ No. } & \multirow[b]{2}{*}{ Perincian } & \multicolumn{3}{|c|}{ Tahapan Siklus } & \multicolumn{3}{|c|}{ Persentase Kenaikan } \\
\hline & & $\begin{array}{l}\text { Kondisi } \\
\text { Awal }\end{array}$ & Siklus I & $\begin{array}{l}\text { Siklus } \\
\text { II }\end{array}$ & $\begin{array}{l}\text { Kondisi } \\
\text { Awal ke } \\
\text { Siklus I }\end{array}$ & $\begin{array}{l}\text { Siklus I ke } \\
\text { Siklus II }\end{array}$ & $\begin{array}{l}\text { Kondisi } \\
\text { Awal ke } \\
\text { Siklus II }\end{array}$ \\
\hline 1. & Rata - rata & 60 & 66 & 74 & $10 \%$ & $12 \%$ & $23 \%$ \\
\hline 2. & Tertinggi & 77 & 80 & 87 & $4 \%$ & $9 \%$ & $13 \%$ \\
\hline 3. & Terendah & 51 & 58 & 68 & $14 \%$ & $17 \%$ & $33 \%$ \\
\hline 4. & $\begin{array}{l}\text { Ketercapaian motivasi } \\
\text { belajar siswa }\end{array}$ & 5 & 17 & 25 & 12 & 8 & 20 \\
\hline 5. & $\begin{array}{l}\text { \% Ketercapaian } \\
\text { motivasi belajar siswa }\end{array}$ & $20 \%$ & $68 \%$ & $100 \%$ & $48 \%$ & $32 \%$ & $80 \%$ \\
\hline
\end{tabular}

Sumber : Data diolah 2018 
Disajikan diagram data kemajuan motivasi belajar siswa dalam pembelajaran kondisi awal, siklus I, siklus II berikut ini.

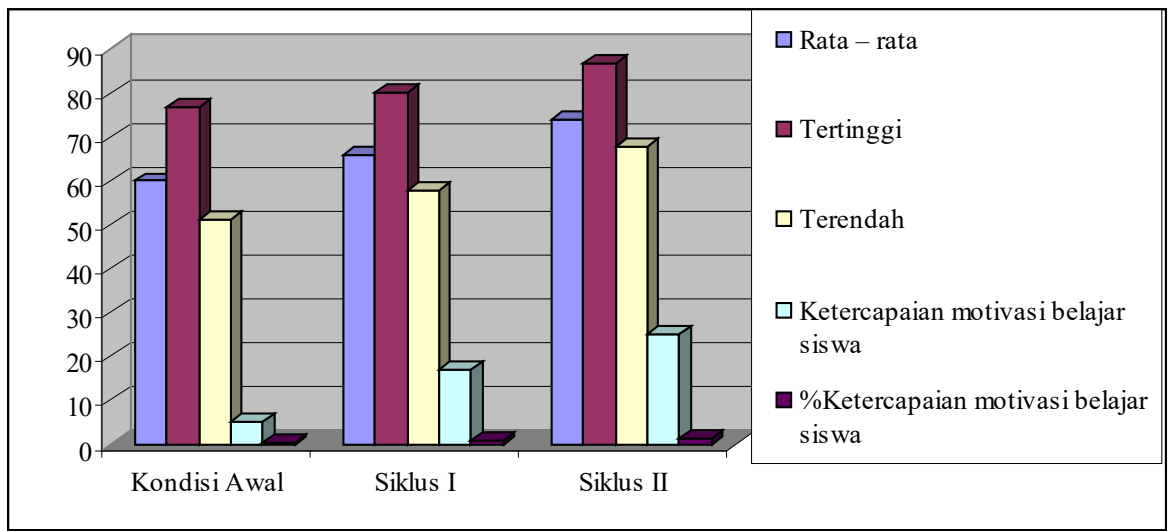

Persentase ketercapaian belajar diperoleh pada kondisi awal sebesar $20 \%$ dan pada siklus I sebesar $68 \%$ serta siklus II sebesar $100 \%$. Motivasi dari kondisi awal ke siklus I siswa terjadi kenaikan ketercapaian kelas sebesar $48 \%$, dari siklus I ke siklus II terjadi kenaikan sebesar 32\%, dan dari kondisi awal ke siklus II terjadi kenaikan sebesar $80 \%$. Hal ini bermakna bahwa motivasi siswa dalam pembelajaran matematika dari kondisi awal hingga siklus II terjadi kenaikan yang signifikan. Dengan demikian, dapat ditegaskan bahwa melalui model discovery learning mengoptimalkan motivasi.

\section{Prestasi Belajar Siswa}

Kemajuan prestasi belajar siswa dalam pembelajaran matematika materi bangun segiempat, pada kondisi awal rata-rata sebesar 60 dan siklus I rata-rata sebesar 67 serta siklus II rata-rata sebesar 80. Dari data ini, tampak jelas bahwa terjadi kenaikan ratarata nilai dari kondisi awal ke siklus I sebesar 7 digit (12\%), dari siklus I ke siklus II terjadi kenaikan sebesar 13 digit (19\%), dari kondisi awal ke siklus II terjadi kenaikan sebesar 20 digit (33\%). Nilai tertinggi prestasi belajar pada kondisi awal sebesar 72, siklus I sebesar 78, dan siklus II sebesar 92. Terjadi kenaikan nilai tertinggi dari kondisi awal ke siklus I sebesar 6 digit (10\%), dari siklus I ke siklus II terjadi kenaikan sebesar 14 digit (18\%), dan dari pasiklus ke siklus II terjadi kenaikan sebesar 22 digit (28\%). Nilai terendah dari kondisi awal sebesar 50, siklus I sebesar 58, dan siklus II sebesar 70. Terjadi kenaikan nilai terendah dari kondisi awal ke siklus I sebesar 8 digit (16\%), dari siklus I ke siklus II terjadi kenaikan sebesar 12 digit (21\%), dan dari pasiklus ke siklus II terjadi kenaikan sebesar 20 digit (40\%).

Tabel 5. Data Kemajuan Prestasi Belajar Siswa Kondisi awal, Siklus I, Siklus II

\begin{tabular}{llcccccc}
\hline & & \multicolumn{3}{c}{ Tahapan Siklus } & \multicolumn{3}{c}{ Persentase Kenaikan } \\
\cline { 3 - 7 } No. & \multicolumn{1}{c}{ Perincian } & $\begin{array}{c}\text { Kondisi } \\
\text { awal }\end{array}$ & Siklus I & $\begin{array}{c}\text { Siklus } \\
\text { II }\end{array}$ & $\begin{array}{c}\text { Kondisi } \\
\text { awal } \\
\text { ke } \\
\text { Siklus I }\end{array}$ & $\begin{array}{c}\text { Siklus } \\
\text { I } \\
\text { Siklus II } \\
\text { ke }\end{array}$ & $\begin{array}{c}\text { Kondisi } \\
\text { awal ke } \\
\text { Siklus II }\end{array}$ \\
\hline 1. & Rata - Rata & 60 & 67 & 80 & $12 \%$ & $19 \%$ & $33 \%$ \\
2. & Nilai Tertinggi & 72 & 78 & 92 & $10 \%$ & $18 \%$ & $28 \%$ \\
3. & Nilai Terendah & 50 & 58 & 70 & $16 \%$ & $21 \%$ & $40 \%$ \\
4. & Ketuntasan Kelas & 6 & 14 & 25 & 8 & 11 & 19 \\
5. & \% Ketuntasan Kelas & $24 \%$ & $56 \%$ & $100 \%$ & $22 \%$ & $44 \%$ & $66 \%$ \\
\hline
\end{tabular}

Sumber : Data diolah 2018 
Disajikan diagram data kemajuan prestasi belajar siswa dalam pembelajaran kondisi awal, siklus I, siklus II berikut ini.

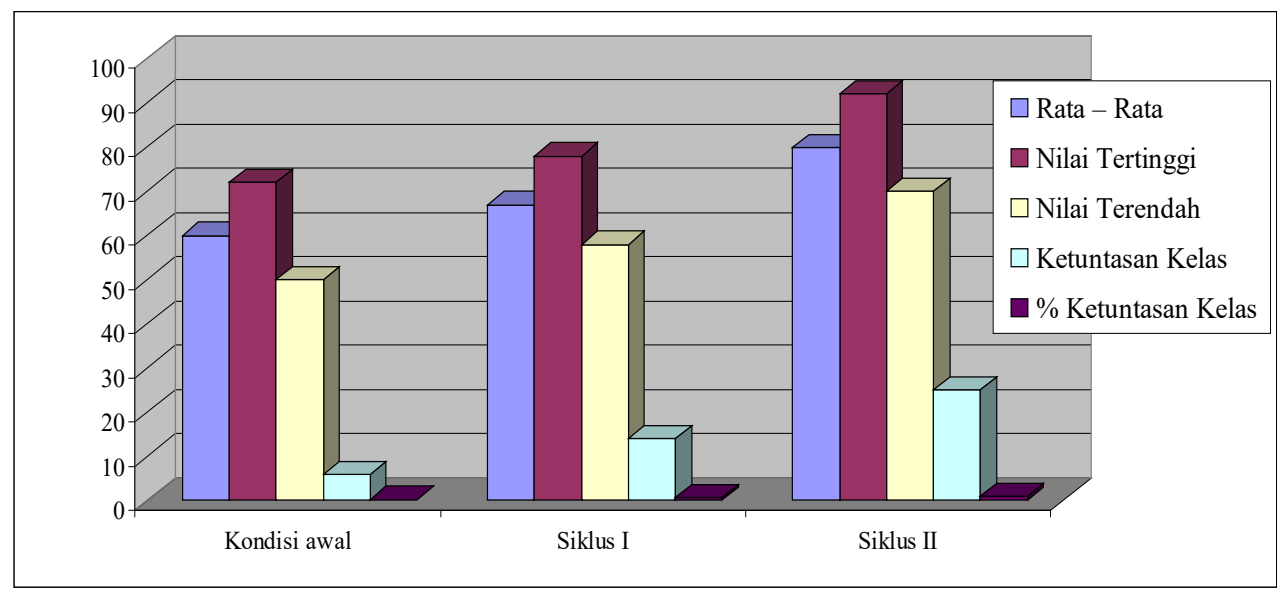

Persentase ketercapaian belajar diperoleh pada kondisi awal sebesar 24\% dan pada siklus I sebesar 56\% serta siklus II sebesar 100\%. Prestasi belajar siswa dari kondisi awal ke siklus I terjadi kenaikan ketercapaian kelas sebesar 22\%, dari siklus I ke siklus II terjadi kenaikan sebesar 44\%, dan dari kondisi awal ke siklus II terjadi kenaikan sebesar $66 \%$. Hal ini bermakna bahwa prestasi belajar siswa dalam pembelajaran matematika dari kondisi awal hingga siklus II terjadi kenaikan yang signifikan. Dengan demikian, ditegaskan bahwa melalui model discovery learning mampu mengoptimalkan prestasi belajar materi bangun segiempat

\section{Penutup}

Hasil penelitian dan pembahasan tentang "Upaya Meningkatkan Prestasi Belajar Materi Bangun Segiempat melalui Model Discovery Learning pada Siswa Kelas VII C SMP Negeri 3 Teras Kabupaten Boyolali Semester Genap Tahun Pelajaran 2017/2018”, dapat disimpulkan bahwa melalui model discovery learning dapat meningkatkan kesiapan dan persiapan guru dalam pembelajaran, meningkatkan motivasi belajar siswa, dan prestasi belajar siswa materi bangun segiempat, karena siswa berperan aktif (student center) dan mampu membangun pengetahuannya sendiri, meskipun tidak terlepas dari bimbingan guru. Model discovery learning sinergis dengan pembelajaran matematika yang memiliki ciri khas antara lain menggunakan permasalahan kontekstual, yaitu permasalahan yang dekat dengan kehidupan siswa, mengembangkan kemampuan pemecahan masalah (problem solving), serta kemampuan berargumentasi dan berkomunikasi secara kritis, memberikan kesempatan yang luas untuk penemuan kembali (reinvention) dan untuk membangun konsep, definisi, prosedur dan rumus-rumus Matematika secara mandiri, melatih cara berpikir dan bernalar dalam menarik kesimpulan, mengembangkan kemampuan berpikir divergen dan kritis yang melibatkan imajinasi, intuisi serta trial and error, dan memperhatikan dan mengakomodasikan perbedaan-perbedaan karakteristik individual siswa. Standar kompetensi dan kompetensi dasar Matematika disusun sebagai landasan pembelajaran untuk mengembangkan kemampuan tersebut.

\section{Daftar Pustaka}

Hanafah, N. dan Cucu S. (2009). Konsep Strategi Pembelajaran. Bandung: PT. Refika Aditama. 
Ilahi, Mohammad Takdir. (2012). Pembelajaran Discovery Strategy dan Mental Vocational Skill. Yogyakarta: Pustaka Pelajar.

Kemendikbud. 2013. Materi Pelatihan Guru, Implementasi Kurikulum 2013. Jakarta: Kementerian Pendidikan dan Kebudayaan.

Oktara Siwi, Setyaningsih N., dan Kholid Noor M. (2015). Penerapan Model Discovery Learning Berbasis Assessment For Learning (AFL) dalam Pembelajaran Matematika Ditinjau dari Optimisme Siswa Kelas XI Semester Genap SMK Negeri 1 Banyudono Tahun Ajaran 2014/2015. Surakarta: Jurusan Pendidikan Matematika Fakultas Keguruan dan Ilmu Pendidikan Universitas Muhammadiyah Surakarta.

Purileila. (2016). Pengaruh Penggunaan Model Discovery Learning dan Model Konvensional untuk Meningkatkan Perilaku Tanggungjawab pada Pembelajaran PKn Siswa Kelas VIII SMP Negeri 19 Bandar Lampung Tahun Pelajaran 2015/2016. Lampung: Program Studi Magister Pendidikan IPS Fakultas Keguruan dan Ilmu Pendidikan Universitas Lampung.

Rasana, R. (2009). Model-Model Pembelajaran. Laporan Sabbatical Leave. Singaraja Undiksha.

Rusmono. (2012). Strategi Pembelajaran dengan Problem Based Learning. Bogor: Ghalia Indonesia.

Suherman, E. H., dkk. (2011). Strategi Pembelajaran Matematika Kontemporer. Bandung: Universitas Pendidikan Indonesia.

Sumantri, Muhammad Syarif. (2015). Strategi Pembelajaran Teori dan Praktik di Tingkat Pendidikan Dasar. Jakarta: Rajagrafindo Persada.

Suryosubroto, B. (2012). Proses Belajar Mengajar di Sekolah. Jakarta: PT Rineka Cipta.

Suwandi, Sarwiji. (2009). Modul Pendidikan dan Latihan Profesi Guru : Penelitian Tindakan Kelas. Surakarta : UNS. 